\title{
Effect of Guided Discovery Teaching Method on Academic Achievement of Upper Basic II Students in English Studies in South South Nigeria
}

\author{
Dr. Vera Idaresit Akpan* $\quad$ Dr. Udodirim Angela Igwe $\quad$ Prof. Theresa Nnennaya Kanno \\ Department of Adult and Continuing Education, Michael Okpara University of Agriculture, Umudike, Abia \\ State, Nigeria
}

\begin{abstract}
The study examined effect of guided discovery teaching method on academic achievement of Upper Basic education students in English Studies in the South-South zone of Nigeria. It was a quasi- experimental research. Two intact classes were randomly selected to constitute a sample size of 100 students for a control and experimental group. Treatment lasted for four weeks and test scores were used as data. Research questions were answered using mean and standard deviation, while ANCOVA was used to test the hypotheses. Results showed that guided discovery teaching method had an increasing positive effect on academic achievement of the students while gender was not a significant factor in this. Recommendations were that teachers should adopt this teaching method in lesson preparation/presentation, school administrators should structure the time table to allow its adoption, while education planners will find the study a good reference material for curriculum renovation and design amongst others.
\end{abstract}

Keywords: guided discovery, teaching method, academic achievement, English Studies.

DOI: $10.7176 / \mathrm{JEP} / 11-29-12$

Publication date:October $31^{\text {st }} 2020$

\section{Introduction}

The achievement of desired instructional or educational goals at the end of a lesson or an educational programme is always assessed by academic achievement and learners' attitude in a given situation. Academic achievement is the evidence gathered from learners through a structured or unstructured test or examination to show the extent of knowledge acquired at the end of a course or programme. Jimoh, Idris and Olatunji (2016) see academic achievement as the degree of success attained after being exposed to one form of learning or the other. This suggests that there is a link between students academic achievement and the teacher's teaching method.

Teaching method is defined by Dorgu (2015) as the strategy by which a teacher delivers his/her subject matter to the learner based on predetermined instructional objectives in order to promote learning in the students. Professionally speaking, teaching method can also be said to be the application of principles and methods by teachers for successful and effective curriculum delivery. Teaching methods are grouped into two broad categories, namely: the teacher-centered and student-centered methods. Between the teacher and student-centered methods of teaching is the guided discovery teaching method that bears some of the characteristics of both methods.

In guided discovery, teaching is viewed as a process of student-teacher interaction; teachers serve the dual role of a teacher and facilitator of learning; students are considered participants in the process and knowledge is constructed by students within the teachers' framework (Kember, 1997). In this method of teaching the principal content of learning is not directly exposed by the teacher but left to be discovered by the learners, making the teacher a guardian and students active participants in the learning process.

A study on the efficacy of guided discovery method of teaching for English Studies in Upper Basic Education is necessary now, considering the fact that this subject cuts across the teaching and learning of all other subjects at this level. Upper Basic education students are children undergoing the Universal Basic Education Programme. The Universal Basic Education (UBE) Programme is a nine (9) year basic educational programme, designed by the Federal government for Nigerian children. It covers six (6) years Primary Education, and three (3) years of Junior Secondary Education.

In Nigeria, English language is the official language of communication used in basic schools, offices, business and skill acquisition. Hence, apart from making good grades in the subject, good communication skill in English language is needed by basic education students to make them become responsible and respectful global citizens, who do not only contribute to the economic well-being of their families and communities but can express themselves formally too. Most UBE graduates are often unable to express themselves properly either orally or in writing (Research and Thesis Support, 2017 \&Adebajo, 2009)). English Studies as currently titled, is a core subject at the Universal Basic Education (UBE) level. This subject cuts across the learning of all other subjects because it is the language of communication. The success of a student in every examination lies to a great extent on students' ability to understand and communicate properly in English language. It is the subject (apart from Mathematics) that determines a pass or failure after a termly, yearly or certificate examination. A credit pass in English Studies 
as a subject determines the promotion of students to a new class and the admission of students to Senior Secondary Schools. It also determines the admission status of candidates into tertiary institutions. It is therefore imperative to carry out a study that would aid the process of curriculum planning and implementation $t$ based on established research as to the choice of an instructional method that could boost academic achievement of male and female students in English Studies (as it is titled in Upper Basic Curriculum) .

Gender issues are becoming very important concepts in education because the society has a demarcation between males and females. Kanno, Ijioma and Obih (2017) define gender as socially or culturally constructed characteristics, rules and qualities which different societies ascribe to males and females which varies from one society to another. If a boy performs poorly the teacher gets so much concerned but if it is a girl the situation is taken very mildly. Consequently an average Nigerian girl who goes to school with these accepted gender stereo types may not be serious with academic achievements. This social construct confines boys and girls not only to roles but also to mental capabilities. These gender stereo types coined by the society and upheld in existing cultures in relation to gender have been considered to be one of those factors that could affect students' academic achievement. One may begin to wonder if the intellect of boys functions differently from that of girls. It is therefore necessary to find out if the use of guided discovery method in teaching English Studies has any effect on gender.

The word effect is defined by Merriam-Webster online dictionary (2019), as that which has the power to bring about a result or cause something to come into being. Again effect is seen as something designed to produce a distinctive or desired impression. In other words, effect is an observable result or change caused by an event, action or the application of a treatment. In this study, the guided discovery teaching method will be administered as treatment meant to produce an observable result or consequence in favour or against male and female upper basic II students' academic achievement.

The problem at hand for this study is revealed in a performance analysis of candidates in 2018 May/June West African Senior Secondary Certificate Examination (WASSCE) carried out by Olarewaju and Alabi (2018). The analysis showed that out of the 1,572,396 candidates that sat for the examination, 786,016 candidates representing $49.98 \%$ obtained credit and above in English Language. The problem revealed by this analysis is the unimpressive number of candidates that failed to have a credit pass in English as a subject which is a prerequisite for employment, admission into higher institution or promotion in career occupation. It therefore becomes necessary to find out if guided discovery teaching method can have an increasing positive effect on academic achievement of male and female basic students in English studies.

Existing literature on this study revealed that Udo (2011) investigated on the effect of collaborative learning (a form of guided discovery method) and lecture method on student academic achievement in English language in Uyo Metropolis. Findings revealed that collaborative learning was more effective in facilitating students' achievement in English language studies than lecture method. It was shown in the results that there was no significant difference between male and female students achievement in English language.

Ida (2017) conducted a quasi-experimental pre-test post-test control group design study to find out whether or not there was any significant difference in reading comprehension achievement between students who were taught by using guided discovery and those who were taught by using conventional method (lecture method) to the eleventh grade students of MAN Arahan, South Sumatra, Indonesia. The result of the study showed that there was significant difference between eleventh grade students of MAN Arahan in south Sumatra in Indonesia, who were taught by using guided discovery and those who were taught by conventional method.

Singaravelu (2012) carried out a study on the effectiveness of guided discovery teaching method in learning English Grammar for the learners at standard V from Bommanampalayam Middle School in India. The Findings of the study revealed that guided discovery teaching method was more effective than traditional methods in learning English Grammar for the students at standard V.

Adigun, Onihunwa, Irunokhai, Sada, and Adesina (2015) studied the relationship between student's gender and academic achievement in computer science in New Bussa, Borgu local government of Niger state. In their results they observed that even though the male students had slightly better performance compared to the female students, it was not significant. Ekhasemomhe (2010) in a study explored the effect of guided discovery teaching on student's achievement in final account in financial accounting in colleges of education in Edo State. The result revealed that guided discovery learning method was more effective in facilitating students' academic achievement. There was no significant difference in the mean scores of male and female students who were taught using guided discovery learning. The female students benefitted more significantly than their male counterparts in achievement test using guided discovery teaching method.

The following research questions were used to guide the study:

1. What is the effect of guided discovery teaching method on the mean achievement score of Upper Basic II students in English studies?

2. What is the effect of guided discovery teaching method on the mean achievement score of male and female Upper Basic II students in English Studies?

The following research hypotheses were formulated and were tested at 0.05 level of significances: 
$\mathrm{HO}_{1} \quad$ There is no significant effect of guided discovery teaching method on the mean achievement score of Upper Basic II students in English studies.

$\mathrm{HO}_{4} \quad$ There is no significant effect of guided discovery teaching method on the mean achievement scores of male and female Upper Basic II students in English Studies.

The study will be of benefit to teachers, students, school administrators, officials of Ministry of Education, curriculum planners and researchers. The result of the study shall also add to existing literature on teaching methods and will be of help in curriculum revision.

\section{Method}

The design of the study was a quasi- experimental research design (the non-randomized $2 \times 2$ factorial pre-test post-test control group design ). Intact classes were used to avoid disruption of the normal school setting. Two instructional methods (guided discovery teaching method and the lecture teaching method) were used as treatments on the male and female subjects to determine the effect on their academic achievement for the experimental and control groups were taught for four weeks. The study area was the South-South geopolitical zone of Nigeria. The population of the study is 693,631 Upper Basic Students. This population is made up of 346,040 males and 347,591 females. The zone has 1387 Upper Basic (Junior Secondary) Schools (FME, 2016). The sample for the study is 100 Upper Basic two students from two Upper Basic Schools. Multi-stage sampling was used to arrive at the final selection of the study sample. The reliability of the instruments used to collect data for the study was established through trial testing and had a reliability coefficient of 0.74 . Students pre-test and post-test scores were used as data for the study. The data were analyzed using mean and standard deviation to answer the research questions while Analysis of Covariance (ANCOVA) was used to test the hypotheses at 0.05 level of significance.

\section{Results}

3.1 Research Question I

What is the effect of guided discovery teaching method on achievement score of Upper Basic II students in English studies?

Table 1: Mean Effect of Guided Discovery Teaching Method on the Mean Achievement Score of Upper Basic II Students in English Studies.

\begin{tabular}{lllllll}
\hline Teaching Method & N & $\begin{array}{l}\text { Pre-test } \\
\text { Mean }\end{array}$ & SD & $\begin{array}{l}\text { Post-test } \\
\text { Mean }\end{array}$ & SD & Mean Effect \\
\hline Lecture & 50 & 46.74 & 11.91 & 53.38 & 10.47 & 6.64 \\
Guided Discovery & 50 & 41.28 & 10.13 & 71.26 & 13.69 & 29.98 \\
\hline
\end{tabular}

Source: Field Survey 2018

Result in Table 1 indicates that the pre-test mean achievement score for control group and experimental group were 46.74 and 41.28 with standard deviation of 11.91 and 10.13 respectively. However, the post-test achievement mean scores for Experimental and control groups were 71.26 and 53.38 respectively with standard deviation of 13.69 and 10.47 respectively. This indicated that guided discovery teaching method has an increasing positive effect on students' achievement in Upper Basic II English studies.

\subsection{Research Question 2}

What is the effect of guided discovery teaching method on the achievement score of male and female students of Upper Basic II students in English studies?

Table 2: Mean effect of Guided Discovery Teaching Method on the Academic Achievement Score of Male and Female Upper Basic II Students in English Studies

\begin{tabular}{lllllll}
\hline Gender & $\mathrm{N}$ & $\begin{array}{l}\text { Pretest } \\
\text { MEAN }\end{array}$ & $\begin{array}{l}\text { Post-test } \\
\text { SD }\end{array}$ & MEAN & SD & Mean effect \\
\hline FEMALE STUDENTS & 31 & 46.28 & 11.53 & 72.06 & 13.95 & 0.43 \\
MALE STUDENTS & 19 & 45.14 & 10.92 & 69.95 & 13.52 & 0.95 \\
\hline
\end{tabular}

Source: Field Survey 2018

Result in Table 2 indicate that the post-test female and male achievement mean score for experimental group were 72.06 and 69.95 respectively with standard deviation of 13.95 and 13.52 with mean effect of 0.43 . This implied that guided discovery teaching method has no effect on the gender of Upper basic II students in English Studies.

\subsection{Hypothesis 1:}

There is no significant effect of guided discovery teaching method on the mean achievement scores of Upper Basic II students in English studies. 
Table 3: Analysis of Covariance (ANCOVA) for the Mean effect of guided discovery teaching method on the mean achievement scores of Upper Basic II students in English studies.

\begin{tabular}{lllllll}
\hline Source of variation & Sum of Squares & Df & Mean Square & F & p-value. & Decision \\
\hline Corrected Model & $10959.803^{\mathrm{a}}$ & 2 & 5479.902 & 45.871 & 0.000 & \\
Intercept & 9519.316 & 1 & 9519.316 & 79.684 & 0.000 & $\mathrm{~S}$ \\
PRETEST & 2967.443 & 1 & 2967.443 & 24.840 & 0.000 & 0.000 \\
GROUP & 9984.920 & 1 & 9984.920 & 83.581 & & \\
Error & 11587.957 & 97 & 119.463 & & & \\
Total & 410926.000 & 100 & & & & \\
Corrected Total & 4101.911 & 87 & & & & \\
\hline
\end{tabular}

a. $\mathrm{R}$ Squared $=.486$ (Adjusted R Squared $=.475), \mathrm{S}=$ Significant

Source: Field Survey 2018

Data analysis in Table 3 shows that the probability value is 0.000 which is less than the alpha value of 0.05 $(\mathrm{p}<0.05)$. This indicate that there was significant effect of guided discovery teaching method on the achievement scores of Upper Basic II students in English studies. Therefore the hypothesis of no significant effect of guided discovery teaching method on the mean achievement score of Upper Basic II students in English studies was rejected.

\subsection{Hypothesis 2:}

There is no significant effect of guided discovery teaching method on the mean achievement scores of male and female Upper Basic II students in English Studies.

Table 4: Analysis of Covariance (ANCOVA) for the Mean effect of guided discovery teaching method on the mean achievement scores of male and female Upper Basic II students pop0-0n English Studies

\begin{tabular}{|c|c|c|c|c|c|c|}
\hline Source of variation & Sum of Squares & Df & Mean Square & $\mathrm{F}$ & P-value & Decision \\
\hline Corrected Model & $900.048^{\mathrm{a}}$ & 2 & 450.024 & 6.455 & 0.049 & \\
\hline Intercept & 671.064 & 1 & 671.064 & 9.625 & 0.033 & \\
\hline Pretest & 592.023 & 1 & 592.023 & 8.491 & 0.045 & \\
\hline Gender & 126.655 & 1 & 126.655 & 1.8166 & 0.542 & NS \\
\hline Error & 3276.887 & 47 & 69.721 & & & \\
\hline Total & 5566.677 & 50 & & & & \\
\hline Corrected Total & 5176.375 & 49 & & & & \\
\hline
\end{tabular}

a. R Squared $=.313$ (Adjusted R Squared $=.196) \mathrm{NS}=$ Not Significant

Data analysis in Table 4 shows the probability value of 0.542 . Since this p-value is greater than the 0.05 alpha $(\mathrm{p}>0.05)$ when tested at 0.05 level of significance, the meaning is that there was no significant effect of guided discovery teaching method on the achievement scores of Upper Basic II in English studies based onz their gender. In other words, guided discovery teaching method had effect was on students' gender. Therefore, the hypothesis of no significant effect of guided discovery teaching method on the mean achievement score of male and female Upper Basic II students in English studies was not rejected.

\section{Discussion of the results}

Results obtained from the study indicate that guided discovery teaching method has an increasing positive effect on students' achievement in Upper Basic II English studies. The students exposed to guided discovery teaching method achieved higher than those exposed to the lecture method. This result agrees with earlier research findings of Ida (2017) who in a study on the effect of guided discovery teaching method on reading comprehension, observed that students taught reading comprehension using the guided discovery teaching method scored higher than those who were taught using lecture method. It was also realized that there was significant difference in reading comprehension achievement between students who were taught by using guided discovery and those who were taught by using lecture method. The result of the present study is also in line with the findings of Singaravelu (2012) who discovered that guided discovery teaching method is more effective than lecture method in teaching English Grammar.

Result of the analysis of ANCOVA revealed that gender was not a significant factor in the effect of guided discovery teaching method on the mean achievement scores of male and female upper basic II students in English Students. This result is in harmony with the findings of Adigun, Onihunwa, Irunokhai, Sada, and Adesina (2015) who realized that even though the male students had slightly better performance compared to the female students, it was not significant. Contrarily, Ekhasemomhe (2010) found that the female students benefitted more significantly than their male counterparts though there was no significant difference in the mean scores of male and female students who were taught using guided discovery teaching method. 


\section{Recommendations}

Following the findings of this study, the following recommendations are made:

1. Since the study revealed that the use of guided discovery teaching method enhances students' academic achievement teachers should adopt this method of teaching in order to help students obtain the required high scores in the subject.

2. Lesson preparation and presentation should be done by teachers to suit guided discovery teaching method where students are made to participate fully in the teaching and learning process. This means that teachers will have to prepare and present lesson content with the view to guiding the students to discover knowledge by themselves as they fully participate in the teaching/ learning process.

3. Teachers should ensure that instructional materials used during lesson presentation are such that are thought provoking so as to generate discussion and interactions among students.

4. Students should be willing to take part in this process of learning because they learn better and retain most of what they do by themselves or in the company of others.

5. School administrators should structure the time table in a way that will allow teachers and students have ample time to employ this method of teaching during lesson periods.

6. School administrators themselves should be conversant with the guided discovery teaching method so that they would be able to supervise the teachers appropriately.

7. Institutes of teacher education responsible for the training of teachers should ensure that the curriculum for teachers deemphasizes the use of lecture method for UBE students while emphasis is laid on the use of guided discovery teaching method.

8. Ministry of education should ensure that updates by way of seminars and workshops on this method of teaching are given to teachers on the job.

9. Government should ensure that classrooms are structured and built to allow easy conversion by the teacher at any time to accommodate the use of any form of guided discovery teaching method.

10. Curriculum planners and designers should draw the attention of authors of English Studies text books to this method of teaching and learning so that the content will be in tandem with the characteristics of guided discovery teaching/learning method.

11. Producers of instructional resources like charts, flash cards, CD ROMs and other learning materials used in the teaching and learning of English Studies should produce to support the use of guided discovery teaching/learning.

12. Gender stereotyping should be discouraged because both male and female students have enviable capacity for academic achievement and particularly in English Studies.

\section{References}

Adebajo, M. (2009). Factors affecting students' performance in English Language in West African School Certificate Examination in Ilesa Local Government Area, Nigeria. A Journal for Teachers of English and Communication skills. 7, 24-31.

Adigun, J., Onihunwa J., Irunokhai, E., Sada, Y. \& Adesina, O. (2015). Effect of Gender on Students' Academic Performance in Computer Studies in Secondary Schools in New Bussa, Borgu Local Government of Niger State. Journal of Education and Practice, 6(33), 1-7.

Dorgu, T. E. (2015). Different teaching methods: a panacea for effective curriculum implementation in the classroom. International Journal of Secondary Education, 3(6), 77-87.

Ekhasemomhe, J. (2010). Effect of guided discovery learning on students achievement in final account in Financial Accounting in Colleges of Education in Edo State. Unpublished M.Ed Thesis submitted to the department of Vocational Teacher Education, University of Nigeria, Nsukka.

Federal Ministry Of Education (2016). Nigeria education indicators 2016. [Online] Available: https://www.nemis.gov.ng/downloads.../Nigeria\%20Education\%20Indicators\%202016.p...

Ida, Z. (2017). The effectiveness of using guided discovery in teaching reading comprehension. Journal Pendidikan dan Pengajaran, 4(2), 2503-2518. Retrieved from http://jurnal.radenfatah.ac.id/index.php/edukasi.

Jimoh, A. G, Idris L O. \& Olatunji B. A. (2016). Effect of jigsaw cooperative learning strategy and gender on students' academic achievement in cost accounting in colleges of education in Ogun State, Nigeria. International Journal of Academic Research in Education and Review.4(5): 150-157.

Kanno, T. N., Ijioma, B. C. \&Obih, S. O. A.(2017). Gender stereotypes and indiscipline: An overview. In U. M Nzewi, T. N.Kanno, V. A. Obasi\&S. O. A. Obih (Eds.), New Perspectives in Gender Studies, Owerri: Mercy Divine Publishers.

Kember, D (1997). A reconceptualization of the research into university academics conception of teaching, Learning and Instruction, 7, 255-275. [Online] Available: http://kb.edu.hku.hk/index.php?id=84

Merriam-Webster (2019). Online dictionary.https://www.merriam-webster.com/dictionary/effect 
Olarenwaju, K. \& Alabi, M. (2018, July 17 )WASSCE results: 10 years of woeful performance. New Telegraph. [Online] Available: https://newtelegraphonline.com/2018/07/wassce-results-10-years-of-woefulperformance/

Research and Thesis Support (2017). BECE 2015: Chief examiner's report for English Language. [Online] Available: http://thesisexamples.blogspot.com/2017/07/BECE-2015-chiefexaminersreport-EnglishLanguage.html

Singaravel, G. (2012). Discovery learning strategies in English. Journal on English Language Teaching, 2(1), 5762. [Online] Available: https://eric.ed.gov/?id=EJ1070208

Udo, A. M. (2011). Instructional strategies and senior secondary school students' academic achivevement in English Language in Uyo metropolis. UnpublishedPh.d Dissertation submitted to the Postgraduate School, University of Uyo, Uyo, Akwa Ibom State, Nigeria. 